4）爾見軍治，七メント技術年報 20，511（1966）。

5) J.D. Watt, D.J. Thorne, J. appl. Chem. 15, 585 (1965).

6) Ya.I. Frenkel, J. Phys. USSR. 9, 385 (1945).
7) G.S. Fulcher, J. Am. Ceram. Soc. 8, 339 (1925).

8) E.P. Knudsen, J. Am. Ceram. Soc. 42, 376 (1959).

\title{
絶縁性窒化物亡高融点金属亡の反応
}

\author{
佐多敏之・浦 野 輝 咢* \\ (東京工業大学 工業材料研究所)
}

\section{Reaction between Refractory Metals and Insulating Nitrides at High Temperature}

\author{
By \\ Toshiyuki SATA and Teruo URANO \\ (Research Laboratory of Engineering Materials, Tokyo Institute of Technology)
}

\begin{abstract}
Some nitrides, $\mathrm{BN}, \mathrm{AlN}$ and $\mathrm{Si}_{3} \mathrm{~N}_{4}$, are used as electric insulators up to moderate temperature. The difficult problems occured when they were to be employed at higher temperatures than $2000^{\circ} \mathrm{C}$. The reactions between those insulators and conductors of refractory metals, tungsten and tantalum, were investigated up to $2100^{\circ} \mathrm{C}$ in a tungsten furnace under argon atmosphere.

In all of the power reactions of $\mathrm{W}$ with $\mathrm{BN}$ with various compositions at $1100^{\circ}$ to $2000^{\circ} \mathrm{C}$ for $2 \mathrm{hrs}$., $\mathrm{W}_{2} \mathrm{~B}$ was first formed, followed by $\mathrm{WB}, \mathrm{W}_{2} \mathrm{~B}_{5}$ and $\mathrm{WB}_{4}$ stepwisely, and nitrogen gas was released. Between $\mathrm{Ta}$ and $\mathrm{BN}$ (50-50 molar composition), TaN, $\mathrm{TaB}$ and small amount of $\mathrm{TaB}_{2}$ were formed. In the reactions between metals and $\mathrm{AlN}$ (50-50 molar composition) for 2 hrs., $W$ did not react, but Ta formed TaN over $1600^{\circ} \mathrm{C}$. Vaporisation $\mathrm{Al}$ and $\mathrm{AlN}$ were observed considerably with elevating temperature. In the reactions between metals and $\mathrm{Si}_{3} \mathrm{~N}_{4}$ (50-50 molar composition) for $2 \mathrm{hrs}$., $\mathrm{W}_{3} \mathrm{Si}_{2}$ and $\mathrm{WSi}_{2}$, and $\mathrm{TaN}$ and $\mathrm{TaSi}_{2}$ were formed, but vaporisation of $\mathrm{Si}_{3} \mathrm{~N}_{4}$ was observed over $1400^{\circ} \mathrm{C}$.

In the reaction between sintered pellets of $W$ and $B N$, reaction layers of $W_{2} B$ and WB were confirmed on the original $\mathrm{W}$ by means of XMA. Here kinetics of formation of $\mathrm{W}_{2} \mathrm{~B}$ from $\mathrm{W}$ and $\mathrm{BN}$ were investigated at the temperatures from $1270^{\circ}$ to $1360^{\circ} \mathrm{C}$ by means of the TGA. By the method of J.H. Sharp et al., the curve of a reaction yield $\alpha$ with a reduced time $t / t_{0.5}$ showed that the reaction rate was controlled by the phase-boundary reaction. An activation energy of this reaction was determined to be $87.0 \pm 17.0 \mathrm{kcal} /$ mole from the Arrhenius plots, and this value is larger than the activation energy 64.0 \pm $6.3 \mathrm{kcal} / \mathrm{mole}$ of diffusion of $\mathrm{B}$ in $\mathrm{W}_{2} \mathrm{~B}$ given by A.P. Epik.

Insulating properties of $\mathrm{BN}$ for $\mathrm{W}$ leads dropped at higher temperature than $1500^{\circ} \mathrm{C}$ owing to the formation of conducting borides. Tungsten borides were easily oxidized in air in the range of $400^{\circ}$ to $600^{\circ} \mathrm{C}$. Their resistivities have a order of $10^{-5} \mathrm{ohm}-\mathrm{cm}$ as metallic conductor. $W_{2} B$ was weak paramagnetic, and $W B$ and $W_{2} B_{5}$ were diamagnetic.
\end{abstract}

[Received Aug. 25, 1969]

1. 緒言

$1500^{\circ} \mathrm{C}$ 以上での電気絶縁の問題は, 真空炉中での種々 の電気測定の際困難な問題であり，精密な測定が行なえ ない状態である。また MHD 発電用電極材料とその絶 縁材料との関係の 困難さも MHD 発電技術開発のネッ クの一つになっている．絶縁物として酸化物が通常使用

* 現在 村堅石扊工業株式会社
されるが，高温で発生する酸素分圧が問題にされると き，軽元素窒化物が絶縁物として好まれる． $1000^{\circ} \mathrm{C}$ 以 下ではその絶縁性は充分であるが，さらに高温では絶縁 性の低下とともに周囲物質との化学反店による低下も充 分考えられると思われる。

以上の観点加ら，高融点金属として通常使用されるタ ングステンとタンタルに焦点を合せ，絶縁物としての窒 
化物に窒化硼素 $\mathrm{BN}$, 窒化アルミニウム $\mathrm{AlN}$, 窒化珪素 $\mathrm{Si}_{3} \mathrm{~N}_{4}$ を取り上げ，それぞれ相互の反応についてしらべ， 特にタングステンと窒化硼素に重点をおいて詳細に研究 した結果をここに報告する。

これに関連した既往の研究については後に触れていく が，2,3 の報告はあるが 基礎的な解明がない現状であ る.このような反応の研究は金属セラミック複合材料の 高温使用や, 金属の嗍化物化, 窒化, 珪化物化の反応に 対しても重要な知識を提供するものと考える.

\section{2. 実 験 方 法}

\section{1 試料と配合}

使用した出発原料はすべて国産品で下表に示した.

タングステン (東京タングステン製), 純度 $99.5 \%$

タンタル (昭和電工製)

I $99.7 \%$

窒化硼素 (BN)（同上）

I) $99.5 \%$

窒化アルミニウム (AIN) (同 上)

窒化珪素 $\left(\mathrm{Si}_{3} \mathrm{~N}_{4}\right)$ (信越化学製)

金属粉末と窒化物とは所要のモル組成で配合し，メタ ノール中で充分乳鉢混合し，僅かのメタノールとともに $3 \mathrm{t} / \mathrm{cm}^{2}$ の圧力で径 $12 \mathrm{~mm}$, 厚さ $1 \mathrm{~mm}$ の 円板に 成形し た.

\section{2 焼成 法}

この成形ペレットの中心に穴をあけ， $0.5 \mathrm{~mm}$ のタン グステン線で炉の中心に釣下げ，アルゴンガス 100 $\mathrm{mmHg}$ の圧力下に加熱した. $1000^{\circ} \mathrm{C}$ まで真空中で約 2 時間で昇温し, 後所定温度までアルゴン中で上昇し, 2 時間その温度に保持して反応させた.

使用した炉 ${ }^{1)}$ は直径 $20 \mathrm{~mm}$, 長さ $150 \mathrm{~mm}$ の円筒状の タングステン・ヒーター(厚さ $0.1 \mathrm{~mm}))$ を持ち, ヒ
一ターの切目 $(4 \times 40 \mathrm{~mm})$ から試料の温度を光高温 計 で測定する.この光高温計は白金の融点で補正した.

\section{3 生成物の測定}

生成物は粉末としX線回折計で同定した。また燒成試 料をダイヤモンド・カッターで切断し，表面を研磨し， 金属顕微鏡で観察した．表- $1^{2)}$ には反応生成物と考えら れる化合物の融点と結晶格子データを示した。

\section{3. タングステンと窒化硼素との反応}

タングステンと BN の配 合モル組成として $90: 10$, $70: 30,50: 50,30: 70,10: 90$ の 5 種類の試料を作り, $1100,1200,1400,1600,1800,2000^{\circ} \mathrm{C}$ の各温度に 2 時 間ずつ加熱し，その生成化合物を表-2 に示した.また 生成量と温度との関係を 図-1 a d 亿示した. 生成量は 同一条件でX線回折を行ない，各化合物の 1 ピークの高 さを使って表わしたもので，生成量の相対的変化のみを 示そうとしたものである。

すなわち W-BN 系反応では W-硼化物のみが生成 し，W-窒化物を生成していない. Langmuir ${ }^{3)}$ は W 融点附近でイオン化あるいはガス状タングステンと解離 した窒素とから窒化タングステンが生成するとした。松 本 $^{4}$ は窒素プラズマ・ゼットを用いてタングステン熔融 物をつくると，蒸発凝縮 した部分に窒化タングステン $\mathrm{W}_{2} \mathrm{~N}$ が生成していること $\mathrm{X}$ 線回折で示している. 一方 $\mathrm{Hägg}^{5)}$ はタングステンとアンモニアとの反応で $250^{\circ} \sim$ $260^{\circ} \mathrm{C}$ で中間化合物としてタングステン・イミドを作り， さらに $700^{\circ} \sim 800^{\circ} \mathrm{C}$ で $\mathrm{W}_{2} \mathrm{~N}$ を得た. その他タングステ ン上に $\mathrm{H}_{2}+\mathrm{NH}_{3}$ 混合ガスを送って $700^{\circ} \sim 1200^{\circ} \mathrm{C}$ の範 囲で $\mathrm{W}_{3} \mathrm{~N}_{4}{ }^{6)}, \beta-\mathrm{W}_{2} \mathrm{~N}^{7)} \mathrm{WN}_{2}{ }^{8)}$ が薄い窒化膜として得 られたと報告されている。このように W と窒素とは活

Table 1. Crystallographic data, melting points and densities of borides, nitrides and silicides of tungsten and tantalum.

\begin{tabular}{|c|c|c|c|c|c|c|c|}
\hline & \multirow{2}{*}{ Form } & \multirow{2}{*}{ Type } & \multicolumn{3}{|c|}{ Lattice parameter (A) } & \multirow{2}{*}{$\underset{\left({ }^{\circ} \mathrm{C}\right)}{\text { Melting point }}$} & \multirow{2}{*}{$\operatorname{Density}\left(\mathrm{g} / \mathrm{cm}^{3}\right)$} \\
\hline & & & a & $\mathrm{b}$ & c & & \\
\hline $\mathrm{W}_{2} \mathrm{~B}$ & tetrag. & $\mathrm{CuAl}_{2}$ & 5.564 & - & 4.740 & $2770 \pm 80,2670$ & 16.72 \\
\hline$\alpha-W B$ & tetrag. & MoB & 3.115 & 一 & 16.93 & $2400 \pm 100,2170^{*}$ & 16.00 \\
\hline$\beta-W B$ & ortho-rhombic & $\mathrm{TaB}$ & 3.07 & 3.19 & 8.46 & $2665,2860-2920$ & 一 \\
\hline $\mathrm{W}_{2} \mathrm{~B}_{5}$ & hexag. & $\mathrm{W}_{2} \mathrm{~B}_{5}$ & 2.982 & - & 13.87 & $2300 \pm 50,2365,2980$ & 13.1 \\
\hline $\mathrm{WB}_{4}$ & tetrag. & $\mathrm{UB}_{4}$ & 6.34 & - & 4.50 & - & 8.40 \\
\hline $\mathrm{Ta}_{2} \mathrm{~B}$ & tetrag. & $\mathrm{CuAl}_{2}$ & 5.778 & - & 4.864 & 1900 & 15.16 \\
\hline $\mathrm{Ta}_{3} \mathrm{~B}_{2}$ & tetrag. & $\mathrm{U}_{3} \mathrm{Si}_{2}$ & 6.184 & - & 3.187 & 2120,2040 & 15.0 \\
\hline $\mathrm{TaB}$ & Orthorhomb. & $\mathrm{TaB}$ & 3.276 & 8.70 & 3.157 & 2430 & 14.29 \\
\hline $\mathrm{Ta}_{3} \mathrm{~B}_{4}$ & " & $\mathrm{Ta}_{3} \mathrm{~B}_{4}$ & 3.29 & 14.0 & 3.13 & 2650 & 13.60 \\
\hline $\mathrm{TaB}_{2}$ & hexag. & $\mathrm{AlB}_{2}$ & 3.078 & - & 3.265 & 3100 & 12.60 \\
\hline $\mathrm{W}_{2} \mathrm{~N}$ & Cub. & $\mathrm{NaCl}$ & 4.118 & - & - & $800-870$ & $>16$ \\
\hline WN & hexag. & $\mathrm{MoC}$ & 2.899 & - & 2.832 & 600 & 15.94 \\
\hline $\mathrm{WN}_{2}$ & rhombohedral & & & & & & - \\
\hline $\mathrm{Ta}_{2} \mathrm{~N}$ & hexag. rhomb. & $\mathrm{Mo}_{2} \mathrm{C}$ & 3.048 & - & 4.918 & $2050, \sim 3000$ & 15.86 \\
\hline $\mathrm{TaN}$ & hexag. & $\mathrm{CoSn}$ & 5.185 & - & 2.908 & $3087 \pm 50$ & 14.36 \\
\hline $\mathrm{W}_{3} \mathrm{Si}_{2}$ & Cub. tetrag. & W & 4.910 & - & - & $2320 \mathrm{~d}$ & 12.21 \\
\hline $\mathrm{W}_{5} \mathrm{Si}_{3}$ & tetrag. & $W_{5} \mathrm{Si}_{3}$ & 9.605 & - & 4.964 & $2320 \mathrm{~d}$ & 12.21 \\
\hline $\mathrm{WSi}_{2}$ & tetrag. & $\mathrm{MoSi}_{2}$ & 3.218 & - & 7.896 & 2165,2115 & 9.87 \\
\hline
\end{tabular}

* phase change to $\beta-\mathrm{WB}+\mathrm{W}_{2} \mathrm{~B}_{5}$ 


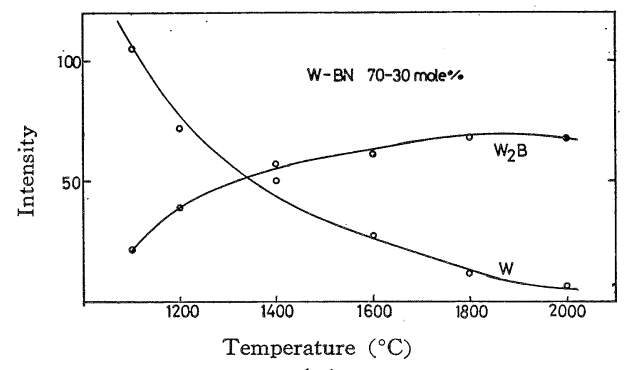

(a)

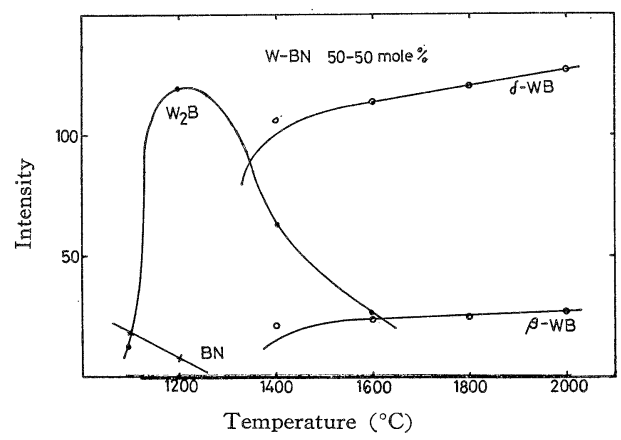

(b)

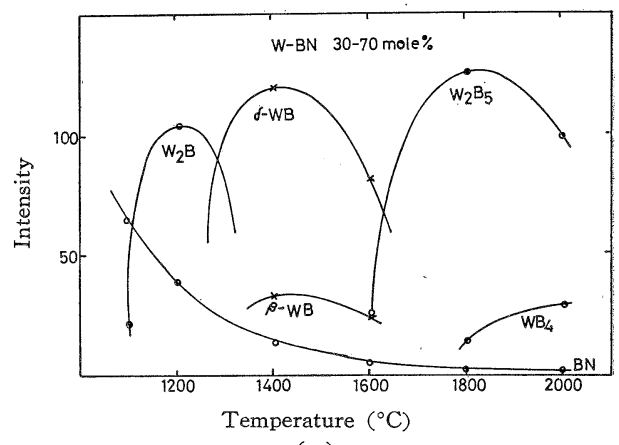

(c)

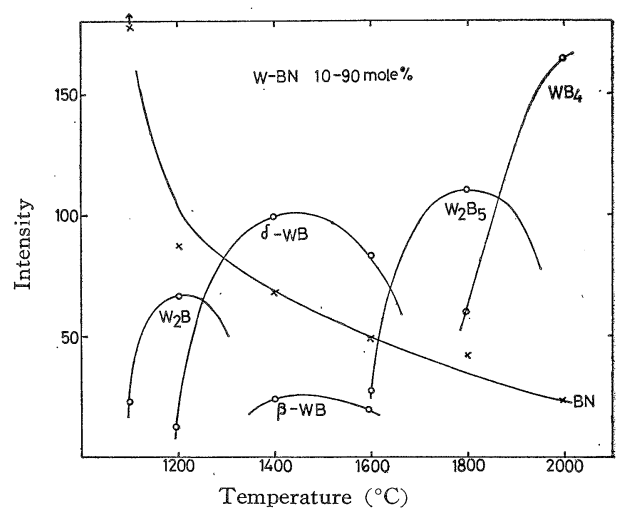

(d)

Fig. 1. Relative amounts of phases present in the products from W-BN reactions for 2 hours in argon at each temperature. Relative amounts were obtained from intensity of a peak on the X-ray diffraction diagram. Initial compositions of $\mathrm{W}-\mathrm{BN}$ in mole $\%$ are as follows: (a) $70-30$, (b) $50-50$, (c) $30-70$, (d) $10-90$

Table 2. Phases present in reaction products between tungsten and boron nitride detected by X-ray diffractometer.

\begin{tabular}{|c|c|c|c|c|c|c|}
\hline \multirow{2}{*}{$\begin{array}{l}\text { W-BN } \\
(\mathrm{mole} \%)\end{array}$} & \multicolumn{6}{|c|}{ Reaction temperature $\left({ }^{\circ} \mathrm{C}\right)$ for 2 hours } \\
\hline & 1100 & 1200 & 1400 & 1600 & 1800 & 2000 \\
\hline $90-10$ & $\mathrm{~W}, \mathrm{BN}$ & $\mathrm{W}, \mathrm{BN}$ & $\mathrm{W}, \mathrm{BN}$ & $\mathrm{W}, \mathrm{BN}$ & $\mathrm{W}, \mathrm{W}_{2} \mathrm{~B}$ & $\mathrm{~W}, \mathrm{~W}_{2} \mathrm{~B}$ \\
\hline $70-30$ & $\mathrm{~W}, \mathrm{BN}, \mathrm{W}_{2} \mathrm{~B}$ & $\mathrm{~W}, \mathrm{~W}_{2} \mathrm{~B}$ & $\mathrm{~W}, \mathrm{~W}_{2} \mathrm{~B}$ & $\mathrm{~W}, \mathrm{~W}_{2} \mathrm{~B}$ & $\mathrm{~W}, \mathrm{~W}_{2} \mathrm{~B}$ & $\mathrm{~W}, \mathrm{~W}_{2} \mathrm{~B}$ \\
\hline $50-50$ & $\mathrm{BN}, \mathrm{W}_{2} \mathrm{~B}$ & $\mathrm{BN}, \mathrm{W}_{2} \mathrm{~B}$ & $\mathrm{~W}_{2} \mathrm{~B}, \alpha-\mathrm{WB}, \beta-\mathrm{WB}$ & $\mathrm{W}_{2} \mathrm{~B}, \alpha-\mathrm{WB}, \beta-\mathrm{WB}$ & $\alpha-\mathrm{WB}, \beta-\mathrm{WB}$ & $\alpha$-WB, $\beta$-WB \\
\hline $30-70$ & $\mathrm{BN}, \mathrm{W}_{2} \mathrm{~B}$ & $\mathrm{BN}, \mathrm{W}_{2} \mathrm{~B}$ & $\mathrm{BN}, \alpha-\mathrm{WB}, \beta-\mathrm{WB}$ & $\alpha-\mathrm{WB}, \beta-\mathrm{WB}, \mathrm{W}_{2} \mathrm{~B}_{5}$ & $\mathrm{BN}, \mathrm{W}_{2} \mathrm{~B}_{5}, \mathrm{WB}_{4}$ & $\mathrm{BN}, \mathrm{W}_{2} \mathrm{~B}_{5}, \mathrm{WB}_{4}$ \\
\hline $10-90$ & $\mathrm{BN}, \mathrm{W}_{2} \mathrm{~B}$ & $\mathrm{BN}, \mathrm{W}_{2} \mathrm{~B}, \alpha-\mathrm{WB}$ & $\mathrm{BN}, \alpha-\mathrm{WB}, \beta-\mathrm{WB}$ & $\alpha-\mathrm{WB}, \beta-\mathrm{WB}, \mathrm{W}_{2} \mathrm{~B}_{5}$ & $\mathrm{BN}, \mathrm{W}_{2} \mathrm{~B}_{5}, \mathrm{WB}_{4}$ & $\mathrm{BN}, \mathrm{WB}_{4}$ \\
\hline
\end{tabular}

性状態でのみ生成するようで，しかも生成した窒化物は $1000^{\circ} \sim 1200^{\circ} \mathrm{C}$ 以上で洨解するようである. 以上のこ とから本実験では窒化物は現われて来ず，BN 中の窒素 は $\mathrm{N}_{2}$ ガスとして脱離した，反応はつぎのように書くこ とができる。

$$
\begin{aligned}
& 2 \mathrm{~W}+\mathrm{BN}=\mathrm{W}_{2} \mathrm{~B}+\frac{1}{2} \mathrm{~N}_{2} \\
& 2 \mathrm{~W}+2 \mathrm{BN}=2 \mathrm{WB}+\mathrm{N}_{2} \\
& 2 \mathrm{~W}+5 \mathrm{BN}=\mathrm{W}_{2} \mathrm{~B}_{5}+21 / 2 \mathrm{~N}_{2} \\
& 2 \mathrm{~W}+8 \mathrm{BN}=2 \mathrm{WB}_{4}+4 \mathrm{~N}_{2}
\end{aligned}
$$

$\mathrm{W}-\mathrm{B}$ 系には $\mathrm{W}_{2} \mathrm{~B}, \mathrm{WB}(\alpha, \beta), \mathrm{W}_{2} \mathrm{~B}_{5}, \mathrm{WB}_{4} \cdots 4$ 化合 物が普通存在し, それらの融点, 不定比性, それらの間 の共融点について報告者 ${ }^{91},{ }^{10}$ によって異なる值が出され ている。また $\alpha-\mathrm{WB}$ 相と $\beta-\mathrm{WB}$ 相とは転移関係にあ
り，その転移温度は $1850^{\circ} \pm 50^{\circ} \mathrm{C}^{11)}, 2400^{\circ} \mathrm{C}^{10)}$ の值があ る. $\mathrm{WB}_{2}$ として以前に報告されたものは $\mathrm{W}_{2} \mathrm{~B}_{5}$ である。 また $W_{12}$ が報告されているが，これが $W_{4}$ といかな る関係があるか不明である。それらの X 線回折結果を 図-2 に示す。

図-1 (a)〜 (d) に示されるように，Wと BN 粉末反 応の経過酒合組成によらず $W_{2} B$ がまず生成し，温度 が上昇するにつれて WB, $\mathrm{W}_{2} \mathrm{~B}_{5}, \mathrm{WB}_{4}$ の順序で階段的 に進行することがはっきりする。 $\mathrm{BN}$ 成分の多い組成で もまず $W_{2} \mathrm{~B}$ が生成することが特徴的である。もちろん 本実験は各温度 2 時間の反応で，W と $\mathrm{BN}$ の残留が一 部見られ，平衡には到達していない時閒範囲である. $\alpha-\mathrm{WB}$ と $\beta-\mathrm{WB}$ とは常に平衡しており，しかも $1200^{\circ} \mathrm{C}$ 


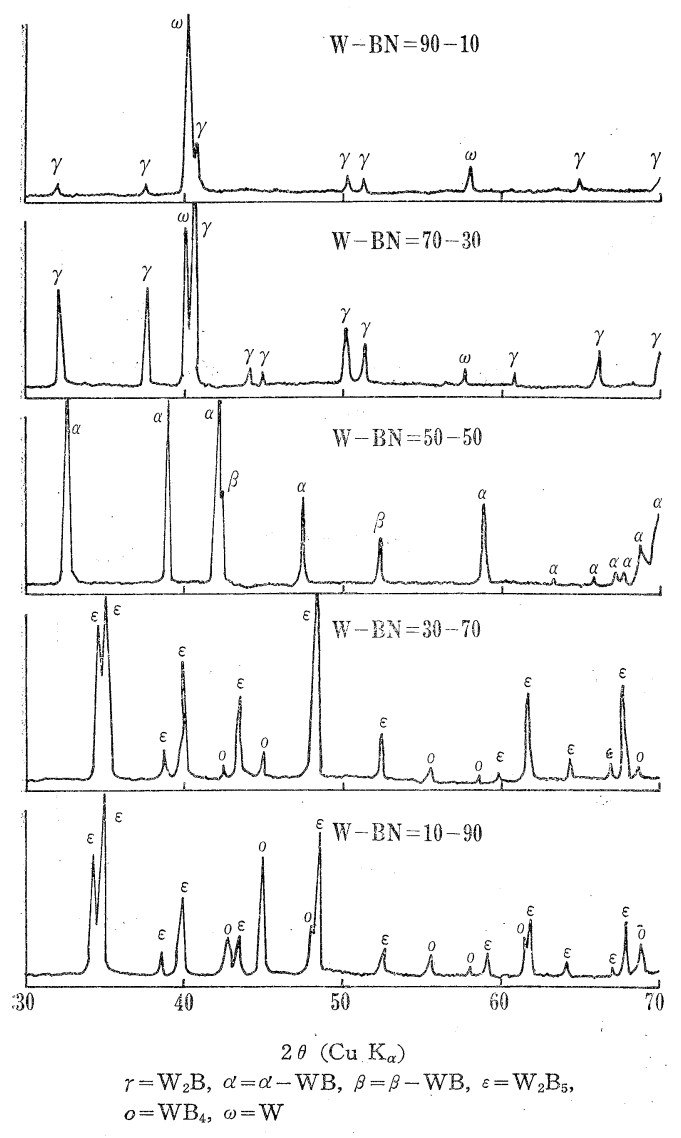

Fig. 2. Examples of X-ray diffraction patterns of reaction products between $\mathrm{W}$ and $\mathrm{BN}$ at $1800^{\circ} \mathrm{C}$ for 2 hours in argon.

以上から生成が見られることは， $\alpha \beta$ 転移温度から考光 てなお不明である。W-BN 系反応については Artamo$\mathrm{nv} ら^{12)}$ が 22 重量 \% BN までの $2060^{\circ} \sim 2250^{\circ} \mathrm{C}$ ホット プレス燒結体をつくり,生成物として $W_{2} B, W B$ を認め ているのが，反応研究として唯一のものである.

\section{4. $\mathrm{Ta} と \mathrm{BN} と の 反$ 応}

50〜50 モル％配合物のみについて，同様に 1200， $1400,1600,1800^{\circ} \mathrm{C}$ の各温度で 2 時間反応させたときの 生成物を表- 3 亿示した。 $1200^{\circ} \mathrm{C}$ では $\mathrm{Ta}, \mathrm{BN}$ の反 応物とともに $\mathrm{TaB}, \mathrm{TaN}$ が生成し, $\mathrm{Ta}_{2} \mathrm{~B}$ も僅か存在す るが，1400 〜 $1800^{\circ} \mathrm{C}$ では $\mathrm{TaB}, \mathrm{TaN}$ のみが $\mathrm{BN}$ とと

$$
\mathrm{Ta}+\mathrm{BN}=\frac{1}{2} \mathrm{TaB}+\frac{1}{2} \mathrm{TaN}+\frac{1}{2} \mathrm{BN}
$$

もに生成する．この反応は $1600^{\circ} \sim 1800^{\circ} \mathrm{C}$ で $\mathrm{BN}$ が消失 するのは，その蒸発によるものと考えられる。1 $1200^{\circ} \mathrm{C}$ で $\mathrm{Ta}_{2} \mathrm{~B}$ が見られるよらに，この反応でも最初に $\mathrm{Ta}_{2} \mathrm{~B}$ の生成があるものと考光られる。

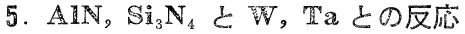

金属と窒化物を 50-50 モル％に配合し，同様に $1200^{\circ}$ $\sim 1800^{\circ} \mathrm{C}$ に 2 時間ずっ加熱して生成物をしらべた. 結 果は一括して表-3に示した。

W-AlN 系ではいずれの温度でも新しい生成物はな く，W と AlN が検出されるのみであり，W の格子定 数も変化していない。しかし試料加熱後の重量減少は $1200^{\circ} \mathrm{C}$ で $1.5 \%, 1400^{\circ} \mathrm{C}$ で $1.7 \%, 1600^{\circ} \mathrm{C}$ で $3.9 \%$, $1800^{\circ} \mathrm{C}$ で $17.6 \%$ と増加して打り， $1500^{\circ} \mathrm{C}$ から急増し ている、蒸着物は $\mathrm{Al}$ の及が検出された。前述のように W がNと窒化物を作らないことを考えると，AIN とし て蒸発したものと考光られる。この結果から W と AlN は $1800^{\circ} \mathrm{C}$ 以下で注反応せす，その温度以上で AlN の 蒸発が著しくなる。

Ta-AlN 系反応では, $1200^{\circ} \sim 1400^{\circ} \mathrm{C}$ で $\mathrm{Ta}$ と $\mathrm{AlN}$ の未反応が残っているが， $1600^{\circ} \sim 1800^{\circ} \mathrm{C}$ で $\mathrm{TaN}$ のみ が生成し， $\mathrm{Al}$ 蒸発している。この場合 $\mathrm{Ta}_{2} \mathrm{~N}$ 注現わ れ流かった。

$\mathrm{W}-\mathrm{Si}_{3} \mathrm{~N}_{4}$ 系 反応では $1200^{\circ} \sim 1400^{\circ} \mathrm{C}$ で未反応物が見 られるが， $1200^{\circ} \mathrm{C}$ から $\mathrm{W}_{5} \mathrm{Si}_{3}$ が見られ， $1400^{\circ} \mathrm{C}$ にな ると $\mathrm{WSi}_{2}$ になる。この場合試料の重量減少は $1200^{\circ} \mathrm{C}$ で $11.1 \%, 1400^{\circ} \mathrm{C}$ で $17.0 \%, 1600^{\circ} \mathrm{C}$ で $26.7 \%$ となり $\mathrm{N}_{2}$ として脱離される以外 $\mathrm{Si}_{3} \mathrm{~N}_{4}$ の蒸発を含んでいると 考えられる。

$\mathrm{Ta}-\mathrm{Si}_{3} \mathrm{~N}_{4}$ 系反応では， $1200^{\circ} \sim 1400^{\circ} \mathrm{C}$ で $\mathrm{Si}_{3} \mathrm{~N}_{4}$ の未 反応物が残留しているが， $1200^{\circ} \mathrm{C}$ で $\mathrm{TaN}$ が見られ， $1400^{\circ} \mathrm{C}$ では $\mathrm{TaSi}_{2}$ が見られる。この反応でも蒝発が著 しい.

以上の結果から W 注窒化物を作ることなく，Ta 法 窒化物が $1200^{\circ} \mathrm{C}$ からでき易い. $\mathrm{Si}_{3} \mathrm{~N}_{4}$ との反応ではい ずれも珪化物をつくる。これらの結果からも低温で最初 に生成するの注金属の多い $\mathrm{W}_{5} \mathrm{Si}_{3}$ である。

\section{6. $W 亡 \mathrm{BN}$ 反応の解析}

これまでの反応实験にもとづき，W-BN 系の初期反

Table 3. Phases present in reaction products between nitrides and refractory metals at 50-50 molar composition.

\begin{tabular}{|c|c|c|c|c|c|}
\hline \multirow{2}{*}{$\begin{array}{l}\text { Reaction } \\
\text { Temperature } \\
\left({ }^{\circ} \mathrm{C}\right)\end{array}$} & \multicolumn{5}{|c|}{ Reaction systems } \\
\hline & $\mathrm{W}-\mathrm{AlN}$ & $\mathrm{W}-\mathrm{Si}_{3} \mathrm{~N}_{4}$ & $\mathrm{Ta}-\mathrm{BN}$ & Ta-AlN & $\mathrm{Ta}-\mathrm{Si}_{3} \mathrm{~N}_{4}$ \\
\hline 1200 & W, AlN & $\mathrm{W}, \mathrm{W}_{3} \mathrm{Si}_{2}, \mathrm{Si}_{3} \mathrm{~N}_{4}$ & $\mathrm{Ta}, \mathrm{Ta}_{2} \mathrm{~B}, \mathrm{TaB}, \mathrm{BN}, \mathrm{TaN}$ & Ta, TaN, AlN & $\mathrm{TaN}, \mathrm{Si}_{3} \mathrm{~N}_{4}$ \\
\hline 1400 & W, AlN & $\mathrm{WSi}_{2}, \mathrm{Si}_{3} \mathrm{~N}_{4}$ & $\mathrm{TaB}, \mathrm{BN}, \mathrm{TaN}$ & TaN, AlN & TaN, $\mathrm{TaSi}_{2}, \mathrm{Si}_{3} \mathrm{~N}_{4}$ \\
\hline 1600 & $\mathrm{~W}, \mathrm{AlN}$ & $\mathrm{WSi}_{2}$ & $\mathrm{TaB}, \mathrm{TaN}$ & $\mathrm{TaN}$ & - \\
\hline 1800 & W, AlN & - & TaB, TaN & TaN & - \\
\hline
\end{tabular}




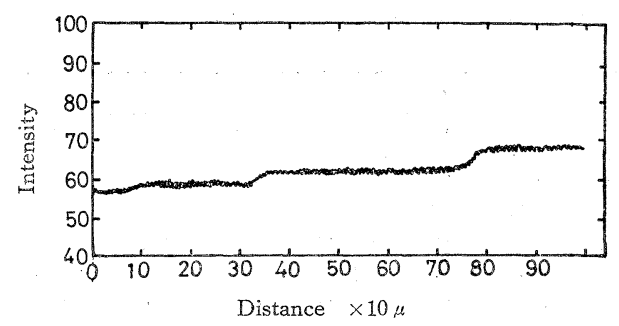

$30 \mathrm{kV}, 0.1 \mu \mathrm{A}, 2 \theta=24.7, \lambda=1.476 \AA$

Fig. 3. X-ray microprobe analyser curve of Wcomponent on reaction layer between tungsten and $\mathrm{BN}$ pellets at $2000^{\circ} \mathrm{C}$ for 2 hours. From left side, each step corresponds to $\mathrm{WB}, \mathrm{W}_{2} \mathrm{~B}$ and $\mathrm{W}$.

応をさらに詳しく検討するため，Wと BN の接触部に おける生成物および W-BN 系粉末間反応の速度をしら ベた。

\section{$6.1 \mathrm{~W}-\mathrm{BN}$ 系接触部における生成物}

新たに水素還元したタングステン粉末を $3 \mathrm{t} / \mathrm{cm}^{2}$ で成 形し $300 \mathrm{mmHg}$ のアルゴン中 $2000^{\circ} \mathrm{C}, 2$ 時間焼結し, 表面を鏡面研磨した。同様に表面を平滑とした $\mathrm{BN}$ ホッ トプレス焼結体と先のタングステン焼結体とを密着さ せ， $300 \mathrm{mmHg}$ アルゴン中 $2000^{\circ} \mathrm{C} ， 2$ 時間反応させた. ついで試料の中央を切断し, 研磨してX線マイクロ・ア ナライザーで検討した.

タングステン燒結体の気孔 率は $24.3 \%, \mathrm{BN}$ のホットプ レス焼 結体の気孔率は 18.2 \%であった，反応後はWの 側にBが侵入して膨脹させて いる. XMAによるBの測定 には満足な值が得られなかっ たので，Wのみについて 測 定し図-3に示した.また表面 から切断してW 濃度一定部 分のX線回折を行ないこれ らの結果から接触面から 330 文ではWB,さらに $750 \mu$ までは $\mathrm{W}_{2} \mathrm{~B}$ であることがわ かり, $\mathrm{W}_{2} \mathrm{~B}$ は $\mathrm{W}$ と接してい る.これらの境界は割合明瞭 である.このことは $\mathrm{W}_{2} \mathrm{~B}_{5}$ が 64〜 70\% B の範囲で不定比 範囲を持つのに対し, $\mathrm{W}_{2} \mathrm{~B}$, WB が定比性化合物である とする報告 ${ }^{10)}$ と合う。以上の ことから $\mathrm{BN}$ 中のBが $\mathrm{W}$ 中 に拡散し，接触部に $W_{2} B$ を 生成している.すなわち W
が搪散して B成分の多い $\mathrm{WB}_{4}$ を $\mathrm{BN}$ 側に生成しないこ とを示している. 以上の結果は $W$ を嘲化物化するとき の結果とよく一致している ${ }^{13), 14)}$.

\section{$6.2 \mathrm{~W}_{2} \mathrm{~B}$ 生成反応速度}

$\mathrm{W}$ と $\mathrm{BN}$ との接触反応の初期には $W_{2} \mathrm{~B}$ がまず生成 することがここれまでの実験で示された。したがって初 期反応として

$$
2 \mathrm{~W}+\mathrm{BN} \rightarrow \mathrm{W}_{2} \mathrm{~B}+\frac{1}{2} \mathrm{~N}_{2}
$$

の反応速度を測定した。

$\mathrm{W}$ 粉末は先に示したもので，これを $1200^{\circ} \mathrm{C} ， 2$ 時間

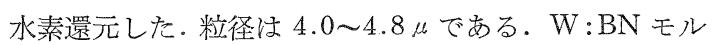
比 $2: 1$ に配合し, 混合して $3 \mathrm{t} / \mathrm{cm}^{2}$ の圧力で円板状に成。 形した。 反応の経過は $\mathrm{N}_{2}$ の脱離による試料の重量減で 測定できる. 重量測定には W 発熱体を持つ自動式熱天 秤 (日新科学 $K K$ 製) を用い，各温度で時閒とともに 重量減少を $\mathrm{X}-\mathrm{Y}$ 記録計に記録させた. 天秤の感度は $0.1 \mathrm{mg}$ である. $1.5 \mathrm{~g}$ の円板試料をアルミナ坩埼に入 れ、アルゴン雾囲気中 $1000^{\circ} \mathrm{C}$ に保って重量の変化のな いことを確め, 後反応温度まで急上昇させた。 反応温度 までの到達時間は 1 分以内であった. $1000^{\circ} \mathrm{C}$ では反応 がおこらないことをあらかじめ確認しておいた。

$1270^{\circ} \sim 1360^{\circ} \mathrm{C}$ での反応率 $(\alpha)$ の時間変化を図-4 に 示した. この結果から J.H. Sharp ら ${ }^{15)}$ の方法に從。

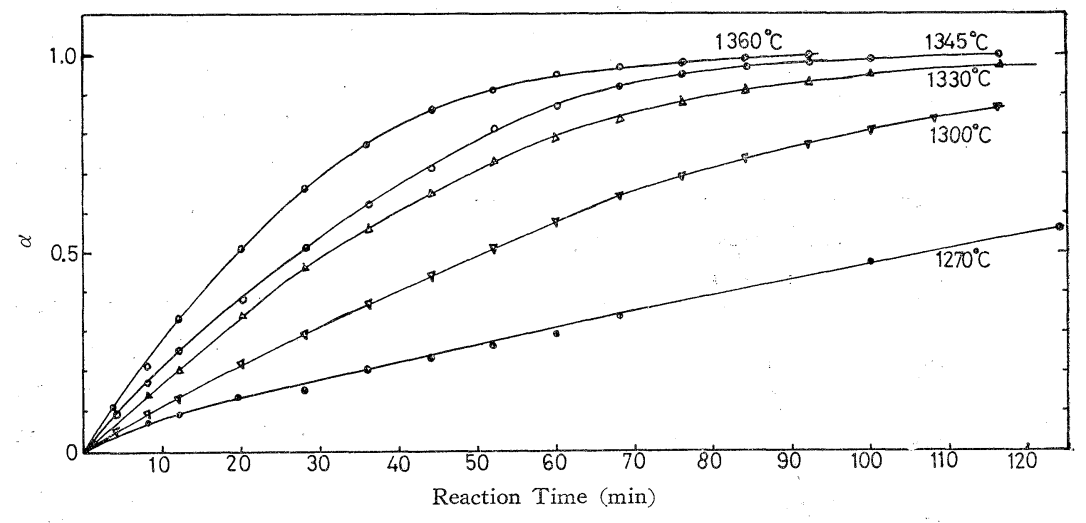

Fig. 4. Reaction yield $(\alpha)$ vs. reaction time $(t)$ in the reaction between $2 \mathrm{~W}$ and $\mathrm{BN}$.

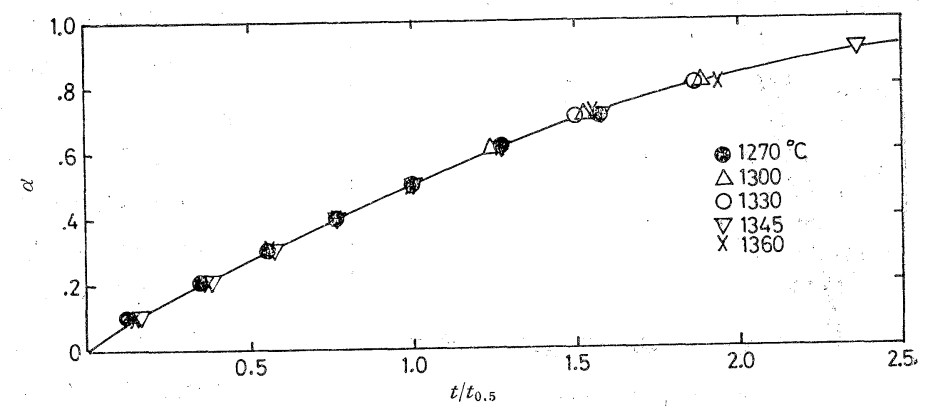

Fig. 5. Reaction yield ( $\alpha$ ) vs. reduced time $\left(t / t_{0.5}\right)$ in the reaction between $2 \mathrm{~W}$ and $\mathrm{BN}$. 
Table 4. Values of reduced time $\left(t / t_{0.5}\right)$ against reaction yield $(\alpha)$ in the reaction between $\mathrm{W}$ and $\mathrm{BN}$ at each temperature.

\begin{tabular}{|c|c|c|c|c|c|c|c|c|c|}
\hline \multirow{2}{*}{ Temperature $\left({ }^{\circ} \mathrm{C}\right)$} & \multicolumn{9}{|c|}{$\alpha$} \\
\hline & 0.1 & 0.2 & 0.3 & 0.4 & 0.5 & 0.6 & 0.7 & 0.8 & 0.9 \\
\hline 1270 & 0.12 & 0.34 & 0.56 & 0.77 & 1.00 & & & & \\
\hline 1300 & 0.18 & 0.36 & 0.56 & 0.77 & 1.00 & 1.24 & 1.52 & 1.88 & \\
\hline 1330 & 0.18 & 0.39 & 0.58 & 0.77 & 1.00 & 1.28 & 1.58 & 1.96 & 2.63 \\
\hline 1345 & 0.15 & 0.34 & 0.55 & 0.76 & 1.00 & 1.27 & 1.56 & 1.87 & 2.36 \\
\hline 1360 & 0.14 & 0.37 & 0.56 & 0.77 & 1.00 & 1.28 & 1.57 & 1.95 & 2.56 \\
\hline Diffusion controlled (a) & 0.028 & 0.121 & 0.295 & 0.576 & 1.000 & 1.628 & 2.568 & 4.051 & 6.747 \\
\hline Phase-boundary reaction controlled (b) & 0.165 & 0.349 & 0.544 & 0.762 & 1.000 & 1.277 & 1.607 & 2.014 & 2.602 \\
\hline
\end{tabular}

(a) $\left[1-(1-\alpha)^{1 / 3}\right]^{2}=\left(k / r^{2}\right) t=0.0426\left(t / t_{0.5}\right)$

(b) $\left[1-(1-\alpha)^{1 / 3}\right]=(u / r) t=0.2063\left(t / t_{0.5}\right)$

て反応率 0.5 亿達する時間 $t_{0.5}$ を求め, reduced time

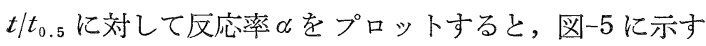
ように各温度ともよく一致した反応率曲線を得た。表-4 には各温度での $\alpha$ に対し $t / t_{0.5}$ の值を求め, 球状粒子の 反応が搪散律速の場合と界面反応律速の場合の $t / t_{0.5}$ と 比較した．この表から反応率曲線が

$$
1-\sqrt[3]{1-\alpha}=0.2063\left(t / t_{0,5}\right)
$$

に相当することがわかる，すなわちこの反応は半径 $r の$ $\mathrm{W}$ の球状粒子の表面加ら 反応が内部に進行し，未反応 界面での化学反応が律速していることを示している．反 応率 $\alpha$ と $t$ 時間の関係は

$$
1-\sqrt[3]{1-\alpha}=(u / r) t=k t
$$

で表わされる、uは反応界面が未反応の内部に向って動 く速度を一定としたときの速度で， $k$ 注速度定数にな る.この式に従って $1-\sqrt[3]{1-\alpha}$ と $t$ の関係をプロットし て図-6 を得, これらの直線から速度定数 $k$ を求めると

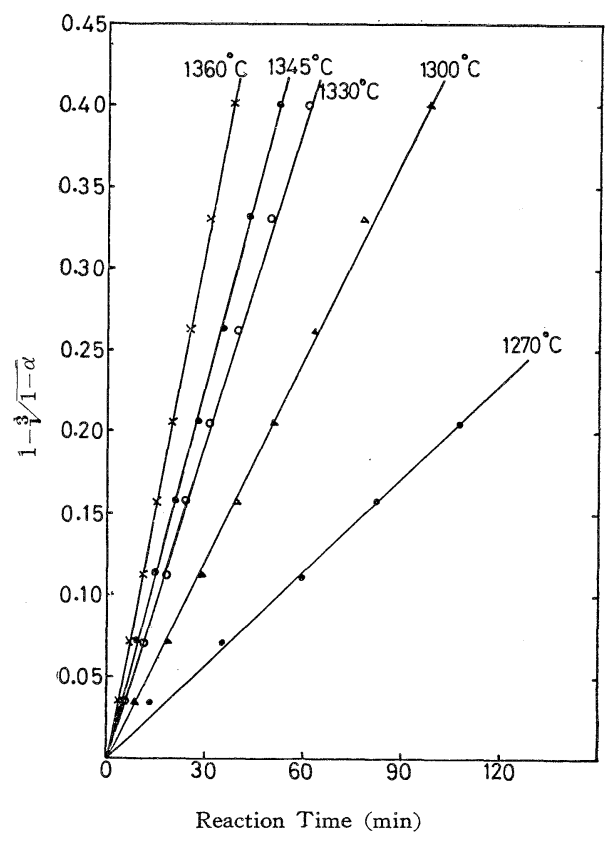

Fig. 6. $1-(1-\alpha)^{1 / 3}$ vs, reaction time $t$ in the reaction between $2 \mathrm{~W}$ and $\mathrm{BN}$.

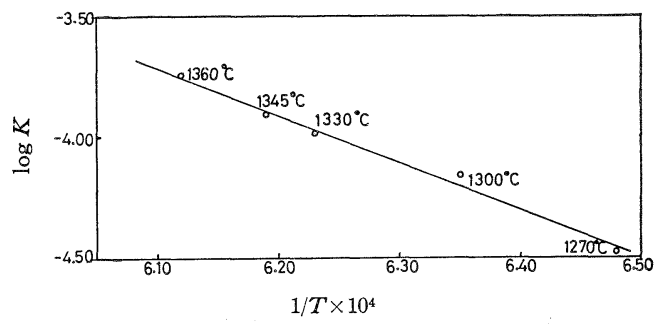

Fig. 7. Arrhenius plots $(\log k-1 / T)$ in the reaction between $2 \mathrm{~W}$ and $\mathrm{BN}$.

$\begin{array}{ll}1270^{\circ} \mathrm{C} & 3.34 \times 10^{-5} \mathrm{sec}^{-1} \\ 1300 & 7.00 \times 10^{-5} " \\ 1330 & 1.07 \times 10^{-4} " \\ 1345 & 1.23 \times 10^{-4} " \\ 1360 & 1.80 \times 10^{-4} \prime\end{array}$

の值が得られ, $\log k$ と $1 / T$ のアレニウス・プロットの 図-7 から反応の見掛けの活性化 エネルギーを求めると, $87.0 \pm 17.0 \mathrm{kcal} / \mathrm{mole}$ を得た。

\section{$6.3 \mathrm{~W}_{2} \mathrm{~B}$ 生成反応機構}

6.1 と 6.2 からこの反応が球状 $\mathrm{W}$ 粒子の表面から内 部に向って抢こる反応であり, その律速過程は外部表面 にできる $\mathrm{W}_{2} \mathrm{~B}$ 層と内部の $\mathrm{W}$ 末反応層との界面反応で あり， $\mathrm{W}_{2} \mathrm{~B}$ 層を通しての拡散過程でないことが推定さ れる. W の密度は $19.3, \mathrm{BN}$ のそれは $2.27 \mathrm{~g} / \mathrm{cm}^{3}$ で, $\mathrm{W} / \mathrm{BN}$ モル比 2 では $\mathrm{W}$ 粒子は BN に充分囲まれた状 態にある。まず $\mathrm{W}$ 表面で $\mathrm{BN}$ が反応分解して $\mathrm{W}_{2} \mathrm{~B}$ 層 をつくり，新たな $\mathrm{BN}$ が $\mathrm{W}_{2} \mathrm{~B}$ 上で反応分解して僅かの $\mathrm{WB}$ 層をつくる. $\mathrm{WB}$ 中の $\mathrm{B}$ 濃度は $\mathrm{W}_{2} \mathrm{~B}$ 中より 高く, $\mathrm{B}$ は $\mathrm{W}_{2} \mathrm{~B}$ 層中を拡散して未反応 $\mathrm{W}$ 表面に到達し, そ こで反応して $\mathrm{W}_{2} \mathrm{~B}$ 層をつくる.一方 $\mathrm{N}_{2}$ は $\mathrm{W}_{2} \mathrm{~B}$ 表面で 脱離する.ここで $\mathrm{B}$ 原子の $\mathrm{W}_{2} \mathrm{~B}$ 相中での拡散の活性化 エネルギーは $1100^{\circ} \sim 1400^{\circ} \mathrm{C}$ で $64.0 \pm 6.3 \mathrm{kcal} / \mathrm{mole}^{14)}$ の值が報告されている.このことから実測值 $87.0 \mathrm{kcal} /$ mole の值からも拡散律速でないことが言える.

W-BN 系反応はアルゴン中および真空中でおこる. しかし $\mathrm{N}_{2}$ 中では $1700^{\circ} \mathrm{C}$ でもおこらない. Kiessling ${ }^{16)}$ は嗍化タングステンが窒素中で $850^{\circ} \mathrm{C}$ 以上の温度で $\mathrm{W}$ $+\mathrm{BN}$ に分解反応するとしている. この反応は $\mathrm{NH}_{3}$ で

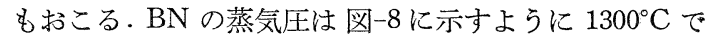




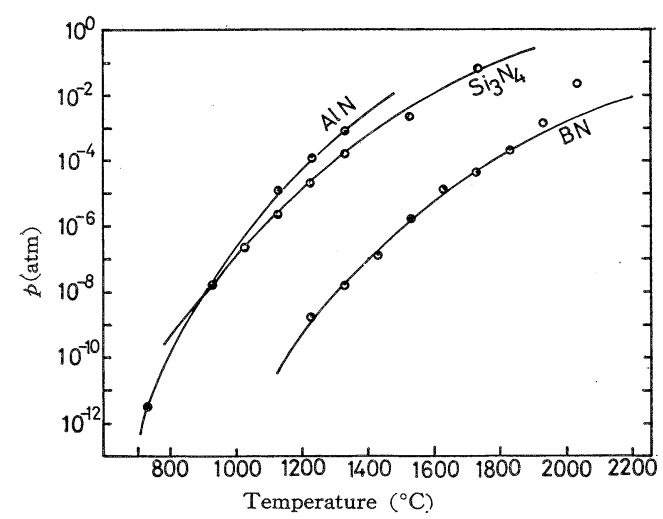

Fig. 8. Vapor pressures of $\mathrm{BN}, \mathrm{AlN}$ and $\mathrm{Si}_{3} \mathrm{~N}_{4}$.

約 $10^{-8} \mathrm{~atm}$ すなわち約 $10^{-5} \mathrm{mmHg}$ で, 充分小さい. $B N$ は蒸発の際は $B+\frac{1}{2} N_{2}$ に分解する.したがって, $\mathrm{BN}$ は $\mathrm{W}$ と嘲化物をつくることで $\mathrm{N}_{2}$ を分離するので あって, W あるいは $\mathrm{W}_{2} \mathrm{~B}$ の触媒作用で分解を促進さ れるのではない.さらに高温, 例えば $1600^{\circ} \mathrm{C}$ では蒸気 压が $10^{-5} \mathrm{~atm}$ となり，それ自身充分分解反応をおこす よらになるので，反応機構は低温の場合とは異ってくる であろう。

\section{7. 導電金属としての $\mathbf{W}$ を用いたときの BN の高温絶縁性の変化}

高温絶縁物として BN を用いるとき, 金属との接触反 応がおき， BN の絶縁性の低下がおこり得る，それは反 応によって生成する硼化タングステンの導電性が良好で あるからである．この反応と絶縁性の低下の関係をしら べる意味でこの測定を行なった． BN の燒結体（径 5

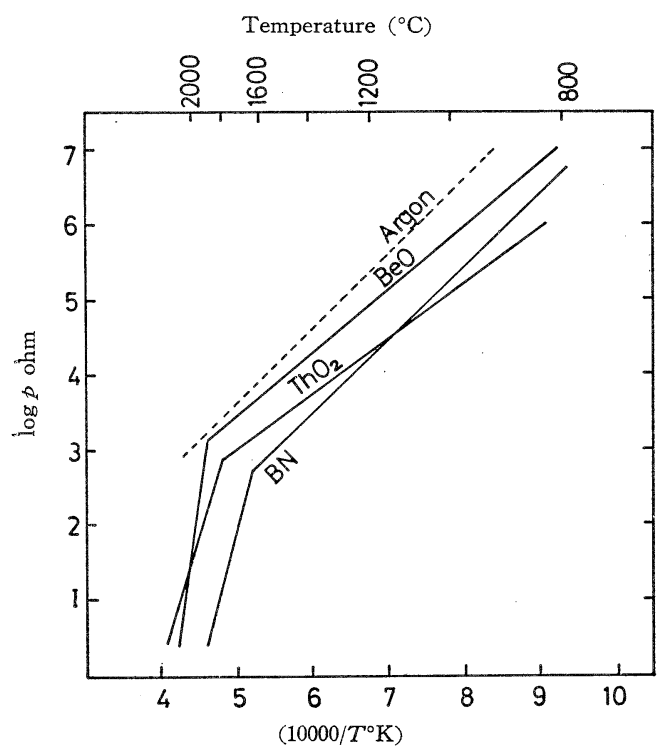

Fig. 9. Electrical resistances of $\mathrm{BN}, \mathrm{BeO}$ and $\mathrm{ThO}_{2}$.

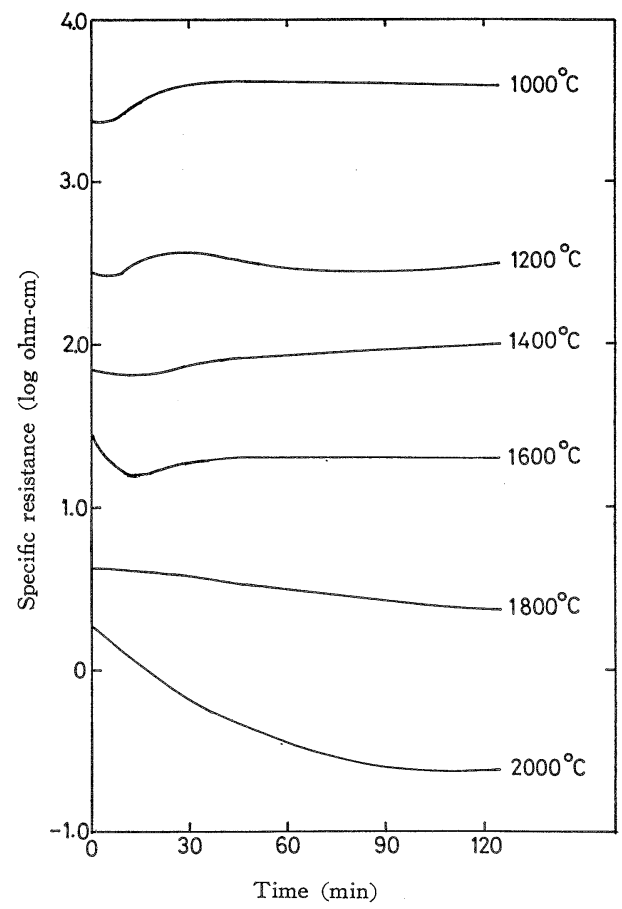

Fig. 10. Variation of electrical resistance of $\mathrm{BN}$ with time.

$\mathrm{mm}$, 厚み $5 \mathrm{~mm}$ ) 中に $1 \mathrm{~mm}$ 径の 2 本の $\mathrm{W}$ 線を間隔 2 $\mathrm{mm}$ で対向させて, この $\mathrm{W}$ 線の両端の電気抵抗を各温 度で測定し，また $1000^{\circ} \sim 2000^{\circ} \mathrm{C}$ での抵抗の時間変化を 測定した. 試料は W ヒーター中に入れ，雾囲気はアル ゴン，測定は交流 1000 サイクルを用い万能ブリッジで 行なった.

温度変化を $\mathrm{BeO}, \mathrm{ThO}_{2}$ の場合と比較して 図-9 に示 した. 比抵抗は $1500^{\circ} \mathrm{C}$ 以上になると急激に低下し, $1800^{\circ} \mathrm{C}$ では 1 桁になる. 活性化エネルギーは $1500^{\circ} \mathrm{C}$ 以

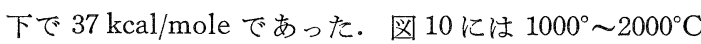
での抵抗の時間変化を示したが， BN の絶縁性の低下は $\mathrm{BeO}, \mathrm{ThO}_{2}$ に較べて大きく, $1600^{\circ} \sim 1800^{\circ} \mathrm{C}$ 以上で著 しくなることがわかる。

\section{8. タングステン硼化物の二，三の物性}

$\mathrm{W}_{2} \mathrm{~B}, \mathrm{WB}$ の単味硼化物と $\mathrm{WB}, \mathrm{W}_{2} \mathrm{~B}_{5}, \mathrm{WB}_{4}$ の混合 物（純粋物を得ることが困難であったためめ）について酸 化特性，電気抵抗および帯磁率の測定を行なった。これ らについて簡単に述べる。

空気中の酸化特性は粉末試料について $1300^{\circ} \mathrm{C}$ まで $5^{\circ} \mathrm{C} /$ 分 の温度上昇速度で TGA を行なった. 図-11 に示 すように約 $400^{\circ} \mathrm{C}$ から酸化が始まり $600^{\circ} \mathrm{C}$ で著しく， $800^{\circ} \mathrm{C}$ でほぼ酸化が完了する．B含量の多いほど酸化増 量が大きくなるのは当然である．酸化生成物は $\mathrm{WO}_{3}$ と $\mathrm{B}_{2} \mathrm{O}_{3}$ のみであった。

電気伝導については $3 \mathrm{t} / \mathrm{cm}^{2}$ 成形物を $2050^{\circ} \mathrm{C}, 2$ 時間 


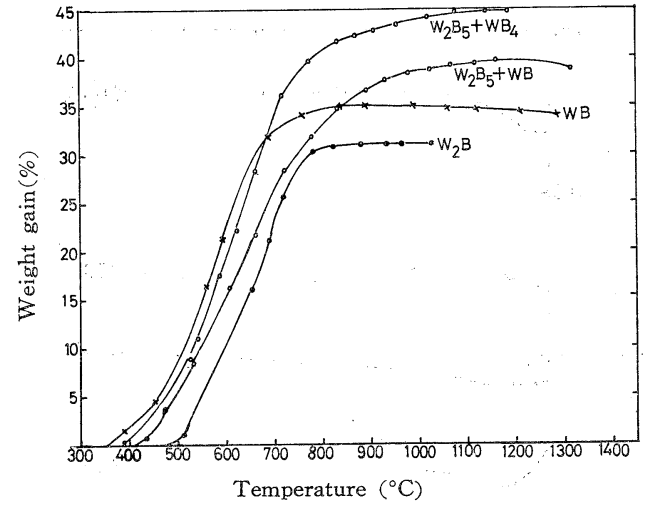

Fig. 11. Weight increases of tungsten borides by air-oxidation.

$400 \mathrm{mmHg}$ のアルゴン中で焼結したもので，気孔率は 下に示すよらに大きく，焼結は不充分であった，測定は 4 端子法で直流を用いて測定した. 常温での比抵抗はつ ぎに示すようである。

$\mathrm{W}_{2} \mathrm{~B}$ 気孔率 $44.2 \%$ 比抵抗 $5.9 \times 10^{-4} \mathrm{ohm}-\mathrm{cm}$

$$
17.7 \quad 3.1 \times 10^{-5}
$$

$\begin{array}{lrl}\text { WB } & 58.6 & 5.9 \times 10^{-4} \\ & 9.7 & 4.5 \times 10^{-5} \\ \mathrm{~W}_{2} \mathrm{~B}_{5}+\mathrm{WB} & 69.0 & 7.6 \times 10^{-4} \\ & 26.5 & 2.9 \times 10^{-5}\end{array}$

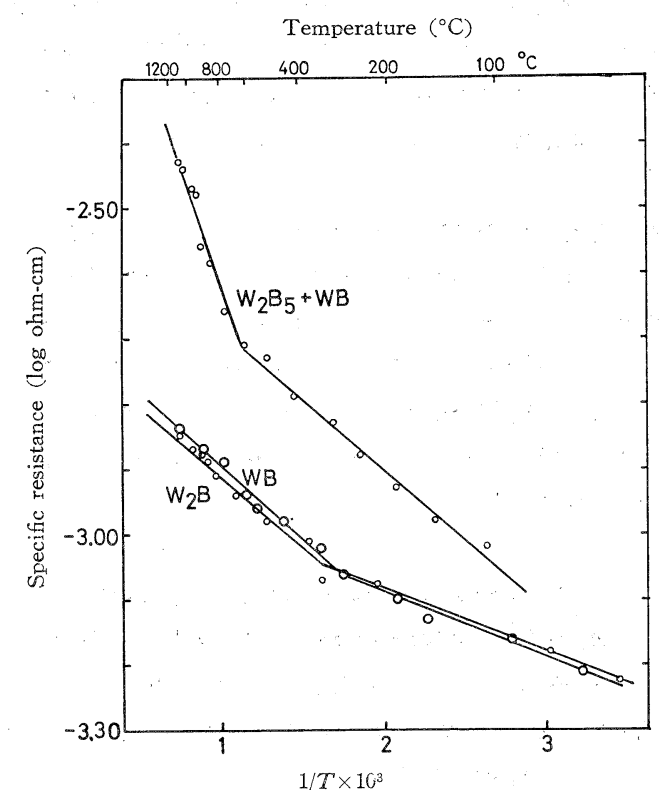

Fig. 12. Electrical resistance of tungsten borides.

また温度変化を図-12 に示した。常温での比抵抗はこれ らの試料であまり異らず，高温ではB成分の含量が多く なるほど比抵抗は増す。また温度が上るとともに比抵抗 の増大があり，その増加も割合少なく，金属と同じ電子 伝導性を示している.
Table 5. Measurement of magnetic susceptibility of tungsten borides.

\begin{tabular}{|c|c|c|c|c|c|c|}
\hline \multirow{2}{*}{ Borides } & \multicolumn{3}{|c|}{ e.m.u./mole, $\times 10^{6}$} & \multicolumn{3}{|c|}{$\begin{array}{l}\text { e.m.u./g-atom } \\
\text { of metal, } \times 10^{6}\end{array}$} \\
\hline & $77^{\circ} \mathrm{K}$ & R.T. & $373^{\circ} \mathrm{K}$ & $77^{\circ} \mathrm{K}$ & R.T. & $373^{\circ} \mathrm{K}$ \\
\hline $\mathrm{W}_{2} \mathrm{~B}$ & 136 & 118 & 114 & 66 & 57 & 55 \\
\hline WB & -25 & -31 & -33 & -24 & -29 & -31 \\
\hline $\mathrm{WB}+\mathrm{W}_{2} \mathrm{~B}_{5}$ & - & - & - & -35 & -40 & -42 \\
\hline
\end{tabular}

磁気的性質については島津製作所製磁気天秤を用い， 石英坩堝の反磁性の補正を加え，硫酸銅を標準として求 め, 結果を表-5に示した. すなわち W $\mathrm{B}$ は弱い常磁性 を示し，その值はW の值 ${ }^{17)}$ とほぼ同じである。温度変 化からパウリの常磁性を示す. $\mathrm{WB}, \mathrm{W}_{2} \mathrm{~B}_{5}$ は反磁性で あるが，その值は小さく，精度はあまり期待できない。

$\mathrm{W}_{2} \mathrm{~B}$ では $\mathrm{W}-\mathrm{W}$ 結合が多く, 導電率から見られるよ らに電子伝導性で，この自由電子の示す弱い常磁性が， 内部の閉款構造の反磁性（軌道反磁性）と対になった電 子の反磁性效果より大きくなったためと考えられる。 $\mathrm{WB}, \mathrm{W}_{2} \mathrm{~B}_{5}$ では $\mathrm{B}-\mathrm{B}$ 結合，W-B 結合がより多くなり， 上記の反磁性の効果が大きくなったためと考えられる.

\section{9. 総括}

高温での導電体である W と Ta と窒化物絶縁体であ る $\mathrm{BN}, \mathrm{AlN}, \mathrm{Si}_{3} \mathrm{~N}_{4}$ との化学反応は $1200^{\circ} \mathrm{C}$ 以上で容易 に始まり，導電性の硼化物，窒化物を生成していき，ま たこれら窒化物の蒸発性も大きくなるので, 高温での絶 縁物として窒化物は適当でない，W-BN 系反応ではど の配合組成でも $W_{2} B$ がまず生成しついで $W B, W_{2} B_{5}$, $\mathrm{WB}_{4}$ の順序で反応が進み， $\mathrm{N}_{2}$ が放出される．この反応 はW 嗍化物の純粋製造にも利用できる. Ta-BN 反応 では $\mathrm{TaN}$ と $\mathrm{Ta}_{2} \mathrm{~B}, \mathrm{TaB}$ が同時に生成する. $\mathrm{AlN}$ との 反応では $W$ とでは反応がおこらず，Ta とでは TaN の 生成功ある。 $\mathrm{Si}_{3} \mathrm{~N}_{4}$ との反応では, W とでは $\mathrm{W}_{3} \mathrm{Si}_{2}$, $\mathrm{WSi}_{2}$ が，Taとでは $\mathrm{TaN}$ と $\mathrm{TaSi}_{2}$ が生成する.いずれ の場合も $1200^{\circ} \mathrm{C}$ 以上で反応が始まる。

$\mathrm{W}-\mathrm{BN}$ 反応の速度の $1270^{\circ} \sim 1360^{\circ} \mathrm{C}$ での測定から $\mathrm{W}_{2} \mathrm{~B}$ 生成反応の活性化 エネルギーは $87.0 \pm 17.0 \mathrm{kcal} /$ mole であり, $\mathrm{B}$ の $\mathrm{W}_{2} \mathrm{~B}$ 層中の桩散は早く, 界面反応律: 速であることが判明した。

$\mathrm{BN}$ の高温絶縁性は $1600^{\circ} \mathrm{C}$ 以上から W Ta, との反 応により低下し, $\mathrm{BeO}, \mathrm{ThO}_{2}$ に劣る.

タングステン硼化物の二，三の物性を測定したが， 空気中での酸化は $400^{\circ} \mathrm{C}$ 以上で急激におこり, $\mathrm{WO}_{3}$ と $\mathrm{B}_{2} \mathrm{O}_{3}$ を生ずる。電気伝導性は金属と同程度であり，電 子伝導性であることが推定される。磁気的性質は $\mathrm{W}_{2} \mathrm{~B}$ が常磁性，WB， $\mathrm{W}_{2} \mathrm{~B}_{5}$ は反磁性であった.

本研究の結果は昭和 42 と 43 年に䇺業協会総会講演会で 発表 した. 
最後に XMA について御指導いただいた東京工大原子炉工学 研究所 鈴木弘茂, 木村脩七両先生に, また各窒化物を御恵与 戴いた昭和電工株式会社, 信越化学工業株式会社に厚くお礼申 し上げる。

$$
\text { 文献 }
$$

1) T. Sata and R. Kiyoura, Bull. of the Tokyo Institute of Tech. No. 53, 39-49 (1963); T. Sata, Rev. Hautes Tempér. et Réfract. 3, 337-41 (1966).

2) Prenum Press Handbook of High-Temperature Materials, No. 1 Materials Index, and No. 2 Properties Index (1964). Am. Cer. Soc., Engineering Properties of Selected Ceramic Materials (1966).

3) J. Langmuir, J. Am. Chem. Soc. 35931 (1913).

4) O. Matsumoto and Y. Hayakawa, J. Electrochem, Soc. Japan 36, 146-53 (1968).

5) G. Hägg, Z. Phys. Chem. B 7, 339 (1930).

6) H.G. Schneider, Neue Huette 8, 494-98 (1963).

7) H. Yamamoto, J. of Japan Inst. of Metals 25, 353-57 (1961).

8) V.I. Khitrova, Kristallografiya, 6, 549-52 (1961).
9) R. Kieffer and F. Benesovsky, Hartstoffe, Wien, Springer (1963).

10) K.I. Portnoi, V.M Romashov, YuV. Levinskii, I.V. Romanovich, Porosh. Met. 7 [5] 75-80 (1967).

11) B. Post and F.W. Glaser, J. Chem. Physics 201050 (1952).

12) A.Y. Artamonov, Y.K. Lapshov, M.V. Kozachenko, D.Z. Yurchencho, and E.M. Dudnik Porosh Met. T [9] 58-63 (1967).

13) G.V.Samsonov, O.P. Epik, Doporidi Akad. Nauk. Ukr. RSR, [1] 67-70 (1964).

14) A.P. Epik, Poroshkovaya Met. Akad. Nauk. Ukr. SSR, 3 [5] 21-27 (1963).

15) J.H. Sharp, G.W. Brindley, B.N. Narahari Achar, J. Am. Ceram. Soc. 49 [7] 379-82 (1966).

16) R. Kiessling and Y.H. Liu, J. of Metals 3 639-42 (1951).

17) C.J. Kriessman, H.B. Callen, Phys. Rev. 94, 837 (1954).

$(8 / 25 / 1969$ 受付)

\title{
溶解熱法によるアルカリ珪酸塩系のエネルギー的検討
}

\author{
ガラスの熱的諸量について（第 1 報）
}

\author{
高 橋 克 明・吉 尾 哲 夫 \\ (岡山大学工学部)
}

\section{Energy Relations in Alkali Silicates by Solution Calorimetry}

(Thermochemical Investigations of Glasses Part I)

By

Katsuaki TAKAHASHI and Tetsuo YOSHIO

(Department of Industrial Chemistry, School of Engineering, Okayama University, Okayama)

The energy relations in some alkali silicate glasses and crystals of the same composition at $25^{\circ} \mathrm{C}$ are reported. The data have been obtained by solution calorimetry in $5 \% \mathrm{HF}$ aqueous solution and, for $\mathrm{Na}_{2} \mathrm{O}-\mathrm{SiO}_{2}$ system, also in distilled water.

The results of these experiments in 5\% $\mathrm{HF}$ aqueous solution are summarized as follows. Heats of solution per $\mathrm{SiO}_{2}$ obtained for both crystals and glasses in the systems $\mathrm{Li}_{2} \mathrm{O}-\mathrm{SiO}_{2}, \mathrm{Na}_{2} \mathrm{O}-\mathrm{SiO}_{2}$ and $\mathrm{K}_{2} \mathrm{O}-\mathrm{SiO}_{2}$ generally show the linear relationship with mole\% alkali oxide in the region above 33.3 mole $\%$ alkali oxide, and show the departure from linearity in the region below 33.3 mole\% alkali oxide. Heats of solution decrease in the order $\mathrm{Rb}>\mathrm{K}>\mathrm{Na}>\mathrm{Li}$ in all compositions. The values of intersecting points obtained by extrapolating the straight line to the ordinate correspond to the heat of solution of $\mathrm{Si}-\mathrm{O}$ $\mathrm{Si}$ network of the alkali silicates. These points gather at the value ca. $11 \mathrm{kcal} / \mathrm{SiO}_{2}$ in crystals and in $\mathrm{Na}_{2} \mathrm{O}-\mathrm{SiO}_{2}$ and $\mathrm{K}_{2} \mathrm{O}-\mathrm{SiO}_{2}$ glasses; this value is ca. $1 / 3$ of the heat of solution of quartz. The enthalpy differences between these glasses and crystals of the same composition decrease in the order $\mathrm{Li}>\mathrm{Na}>\mathrm{K}$.

From the results of experiments of solution calorimetry in distilled water in the system $\mathrm{Na}_{2} \mathrm{O}-\mathrm{SiO}_{2}$, it has been found that the sodium component is dissolved and weakpoints in $\mathrm{Si}-\mathrm{O}-\mathrm{Si}$ bonds are broken to form poly-silicic acids. The average number of $\mathrm{Si}$ contained in a poly-silicic acid discrete anion formed by the dissolution of crystals are 2 to 